\title{
Seismic Performance of Wide-Beam Infill-Joist Block RC Frames in Turkey
}

\author{
Cemalettin Dönmez ${ }^{1}$
}

\begin{abstract}
Observations after the 2011 Van-Erciş earthquake show that some of the recently constructed reinforced-concrete buildings were either heavily damaged or had collapsed. As a building subtype, wide-beam, infill-joist block reinforced-concrete frames got attention because of their mode of failure. There were several such buildings that failed in strong-column, weak-beam mode. Considering the demand created by the earthquake, structures were not expected to reach their full capacity. The purpose of this study is to review the history and current practice of infill-joist frames in Turkey and to conduct a performance evaluation of infill-joist frames designed per the current earthquake code (2007). Regulations for this building subtype are critically reviewed, and the designer's response to code regulations is discussed. Results indicate that the force-based design approach used in the current code is not always adequate to satisfy the displacement demands. In addition, it is observed that layout, proportioning, and detailing requirements of beam-end regions and beam-column connections do not always warrant ductile behavior as targeted. DOI: 10.1061/(ASCE)CF.1943-5509.0000485. @ 2014 American Society of Civil Engineers.
\end{abstract}

Author keywords: Reinforced concrete; Seismic design; Performance-based design; Wide beams; Turkey.

\section{Introduction}

Failure of wide-beam, infill-joist reinforced concrete (RC) frames during the 2011 Van-Erciş earthquake $\left(M_{w}=7.1\right)$ attracted attention to the seismic behavior of these structures. There were no ground motion records from Erciş (population 80,000, $39 \mathrm{~km}$ from the epicenter), the city hardest hit with nearly 200 totally or partially collapsed buildings. The nearest record was in Muradiye (40 km from the epicenter) with a $0.18 \mathrm{~g} \mathrm{~N}-\mathrm{S}$ component. Even though Muradiye is about the same distance from the epicenter of the earthquake, the degree of damage was more extensive in Erciş. Therefore, it is believed that Erciş had ground shaking stronger than that in Muradiye (Irfanoglu et al. 2012). Field investigations (Irfanoglu et al. 2012; METU 2012) revealed that damaged structures typically did not follow the code requirements with regard to structural layout, detailing, and quality of material. Nevertheless, damage in infill-joist systems deserve closer study due to their mode of premature failure in the form of strongcolumn, weak-beam mode despite earthquake demands that were lower than design level.

Reinforced-concrete moment frames are the most common structural systems used in building construction in Turkey. As a subtype, wide-beam RC frames with a relatively thin slab and one-way joists are second to regular RC moment frames. This type of construction has become very popular in recent years and is now widely used in the region and in the rest of the country. Typically, voids between the joists are filled with a special type of clay brick that is called "asmolen." The whole slab system is also called "asmolen." As alternatives, styrofoam or hollow cinder blocks could also be used as filler material. The wide beams of asmolen systems are selected to be as deep as the joists, with typical

\footnotetext{
${ }^{1}$ Associate Professor, Civil Engineering Dept., Izmir Institute of Technology, Urla, İzmir 35430, Turkey. E-mail: cemalettindonmez@iyte .edu.tr

Note. This manuscript was submitted on November 8, 2012; approved on June 10, 2013; published online on June 13, 2013. Discussion period open until November 5, 2014; separate discussions must be submitted for individual papers. This paper is part of the Journal of Performance of Constructed Facilities, (C) ASCE, ISSN 0887-3828/04014026(9)/\$25.00.
}

width-to-depth ratios of 2 to 3 . Frames up to ten floors are built by using this system. In common practice, only moment frames are used in up to six floors, and structural walls are added for taller structures. An eight-story example is presented in Fig. 1. Other Mediterranean countries have similar systems in their construction practices as well (Benavent-Climent 2006). There are two main reasons for popularity of wide-beam, infill-joist block systems: the finished flat-bottom surface provides flexibility in architectural considerations, and construction costs decrease by savings in the formwork. Due to the nature of the prescribed equivalent lateralload procedure in the codes, inherent flexibility of the frame causes a decrease in lateral design forces with the bonus of naturally achieved strong-column, weak-beam behavior. Design engineers who are accustomed to thinking in terms of a force-based approach may not notice that these systems would be subjected to increased displacement demands.

Considering the seismic codes in Turkey, design requirements for asmolen buildings have had an irresolute path. Upon observation of failures in the 1967 Adapazarı earthquake, the use of asmolen systems was forbidden. However, in the 1975 code (TCBIB 1975), its use in seismic areas was permitted only for structural wall buildings shorter than a certain height. The definition of a structural wall building was not very clear in the 1975 code. Obviously, code developers were aware of the excessive flexibility of the asmolen system and were warning engineers implicitly through the structural wall requirement. With the 1997 code, it is permitted to design asmolen systems as pure moment-frame structures again. The main requirement to satisfy is to ensure a frame with high ductility by using the recommended recipe of the code.

The objective of this paper is to review the performance of asmolen buildings during earthquakes in Turkey, to summarize the current knowledge about the seismic performance of wide-beam frames, and to present typical proportions and practice of asmolen structures in Turkey. In addition, the adequacy of the existing requirements to satisfy code performance targets is also investigated.

Seven existing RC frames with infilled joist floors are studied to investigate the typical proportions and displacement capacity of asmolen structures. Selected structures have three to six stories to represent existing variations through changes in the number of floors. 

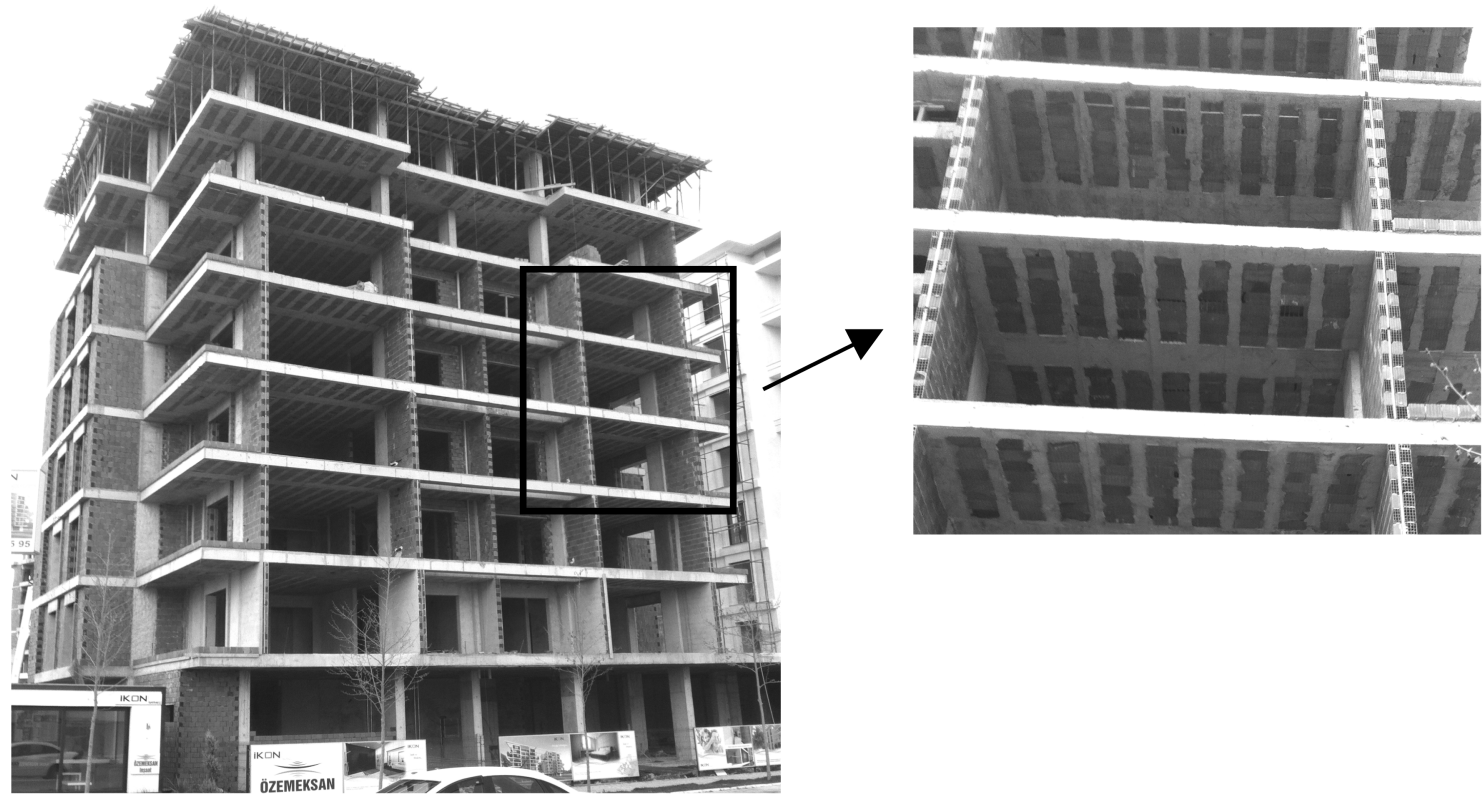

Fig. 1. An eight-story asmolen structure in İzmir (a high seismicity area) (images by Cemalettin Donmez)

Current code requirements and the designers' response within the context of the selected buildings are discussed together to present the unintentional effects of the code on the final design.

\section{Reported Performance of Asmolen Buildings in Earthquakes in Turkey}

The first available observation on seismic performance of asmolen buildings in Turkey dates back to the 1967 Adapazarı earthquake (Arığlu et al. 2007; Ersoy 1991; Pekin 1967). It was reported that eight asmolen buildings had collapsed during that earthquake. Even though no technical details were provided about these collapsed buildings, asmolen buildings were banned in high-seismicity regions after the 1967 Adapazarı earthquake. However, they were permitted again by the 1975 earthquake code. No records about the performance of asmolen buildings are available from major earthquakes after the 1967 Adapazarı until the 1992 Erzincan earthquake [1970 Gediz (Yarar et al. 1970); 1975 Lice (TCïiB 1975); 1978 Muradiye-Çal (Gülkan et al. 1978); 1983 Erzurum-Kars (TCBİB 1983) earthquakes]. This absence of reports could be attributed to the rural character of the earthquake-stricken areas. Asmolen system damages were reported in the 1992 Erzincan earthquake (AFET 1993; Malley et al. 1993). The state hospital building that was composed of six blocks sustained heavy damage. Relatively new blocks that were reported to be of asmolen type totally collapsed. Older units that had RC moment frames and regular beam-column slab floor systems sustained heavy damage but survived the earthquake without collapse.

Further reports are available from the 1998 Adana-Ceyhan earthquake (Gulkan 1998). It is reported that most of the buildings in Ceyhan were RC frames with asmolen floors. The main features of buildings are listed as five to seven stories, rectangular columns with a smaller dimension of $250 \mathrm{~mm}$, no structural walls, narrow partition walls, cantilevering floors above the ground story, and open ground floors. Twelve asmolen buildings collapsed, and many others sustained damage. It is noted that material quality, workmanship, and detailing were inferior in all of the collapsed buildings.
The 1999 Izmit earthquake provided more examples of damaged asmolen buildings. Interestingly, it is documented that some of the asmolen buildings failed due to the weak vertical elements as compared to horizontal members (Aschheim et al. 2000; Saatcioglu et al. 2001). Reports also include the common deficiencies of RC buildings including the asmolen buildings. These deficiencies are insufficient transverse reinforcement in detail, location and spacing. The unintended interference of the nonstructural elements with the structural system. The irregularities in structural system impairing the deformation capacities of the structures and the improper structural layouts causing torsion and/or soft and weak stories.

The 2011 Van-Erciş earthquake caused widespread damage (Baran et al. 2013; Bayraktar et al. 2013; Irfanoglu et al. 2012; METU 2012; Okuyucu et al. 2014). Damage in asmolen buildings is also reported (Irfanoglu et al. 2012; METU 2012). Observed damages are listed within the general RC frame group with similar common deficiencies as defined in previous earthquakes.

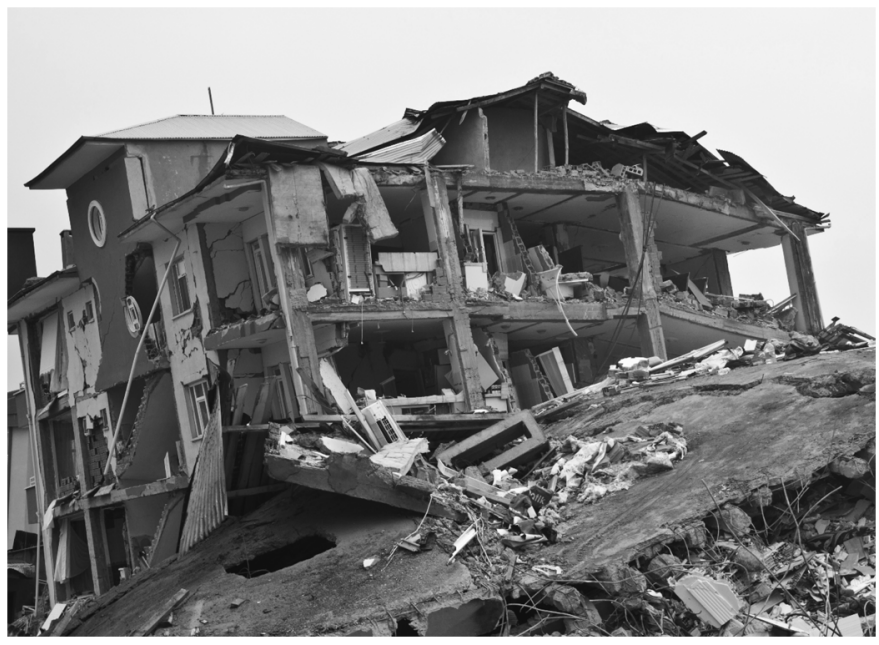

Fig. 2. Collapsed asmolen buildings in Van-Erciş 2011 earthquake (image courtesy of I. Bedirhanoglu) 
An example of a partially collapsed asmolen building in Erciş is presented in Fig. 2. It can be observed from the figure that the frame failed in the strong-column, weak-beam mode of failure.

A review of reports reveals that asmolen buildings, as a common subtype of RC frames, were not specifically investigated or reported on after earthquakes. The reason behind this tendency could be the code-defiant designs of the existing buildings. It is observed that deficiencies in the material and member level were so overwhelming that failures in earthquakes did not present any distinct behavior of asmolen systems.

\section{Cyclic Lateral Load Performance of Wide-Beam Column Systems}

Due to their relatively high flexibility and bond issues regarding the longitudinal bars, structural engineers are concerned about the seismic behavior of wide-beam systems. A detailed review of the literature about lateral load behavior of wide-beam systems is presented by Benavent-Climent et al. (2010). Based on experiments, it is reported that the critical issues that need to be addressed in the design of wide-beam systems are (1) geometry of the connecting members and connection details, (2) development of flexural bars outside the column core, and (3) control of slip that takes place in the longitudinal bars of columns and beams. In 1991, the ACI-ASCE-352-02 (ASCE Committee 352 2002) committee recommended that wide-beam systems should not be used in high-seismicity areas. Later in 2002, the committee modified this recommendation by allowing usage under a set of conditions. Similarly, ACI 318-11 (American Concrete Institute 2011) agreed with the use of wide beams subject to certain conditions. It is required that a wide beam should have a width that is less than the sum of 1.5 times the column width perpendicular to the beam, $w_{c}$, plus the beam depth, $d_{b},\left(1.5 w_{c}+d_{b}\right)$. Additionally, longitudinal beam bars outside the column core are required to be confined by transverse reinforcement.

Some researchers (Benavent-Climent et al. 2010; Gentry and Wight 1994; Lafave and Wight 2001) reported that wide-beam moment resistance at column connections is affected by three main parameters: the ratio of the bars anchoring to the column core, the development of a strut mechanism in the vicinity of the column, and torsion resistance of the spandrel beams. Beam and slab reinforcements that are away from the column core are observed to be anchored through torsional resistance of spandrel beams. If both strength and stiffness are important, it is recommended that torsional-cracking strength of the spandrel beams should be higher than the capacity of anchoring beam and slab bars. If necessary, the required capacity could be provided through torsion reinforcement in the spandrel beams but with a compromise in stiffness of the system. Beam and slab bars that are relatively closer to the column are reported to be developed through a strut mechanism as well. The effective width over which the strut mechanism is observed is defined as half of the column dimension in the direction of the beam (Benavent-Climent et al. 2010). It is noted that to mobilize this action, sufficient tension reinforcement in the spandrel beam should be provided to compensate for the compressive forces in the strut. The development of column and beam bars is reported to depend on bond length provided by column and beam depth The ACI-ASCE-352-02 report (ASCE Committee 2002) recommended that in order to control the slip of bars, column and beam widths should be at least 20 bar diameters of the column and beam flexural bars, respectively.

It is important to note that existing test results are on concentric wide-beam column connections. There is no data on eccentric connections. Based on this fact, ACI-ASCE-352-02 does not recommend the use of eccentric wide beams in high-seismicity areas.

\section{General Dimensions and the Code Requirements of Asmolen Systems in Turkey}

Current Turkish seismic code [TEC-2007 (TCBİB 2007)] permits asmolen buildings in high-seismicity areas with the condition that these structures should be designed under high-ductility frame requirements for regular RC moment frames. These requirements are in accordance with the modern codes in other high-seismicity regions of the world. Asmolen buildings are typically designed by the equivalent static earthquake load method due to their common size and geometry. Interstory drift ratios under lateral loads are required to be less than $2 \%$, which is calculated by a linear analysis. No reductions are proposed for flexural rigidities of members for drift analysis.

Due to inherent flexibility, typically the drift limit governs the member design of asmolen buildings. Due to limited beam depth and architecturally controlled spans, column size and geometry are the only design parameters modified to satisfy the current code drift requirements. A limited amount of structural walls are common, to satisfy the drift requirement of the code as well.

External dimensions of asmolen buildings are very similar to typical RC moment-frame construction in Turkey. Plan dimensions vary considerably, and footprints range as large as 16 by $33 \mathrm{~m}$. Story heights are typically 2.7 to $3 \mathrm{~m}$, with the exception of a taller ground story, which may be as high as $4.6 \mathrm{~m}$. The one-way slab formed by the joists results in heavily loaded girders in the perpendicular direction and lightly loaded in the other. A typical geometry for asmolen floor systems is presented in Fig. 3. The span

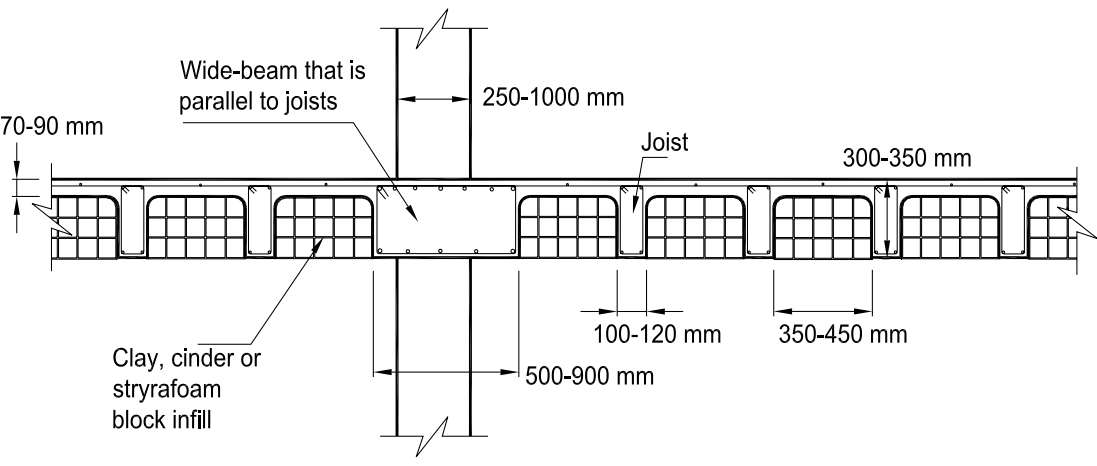

Fig. 3. Typical dimensions of asmolen floor systems 


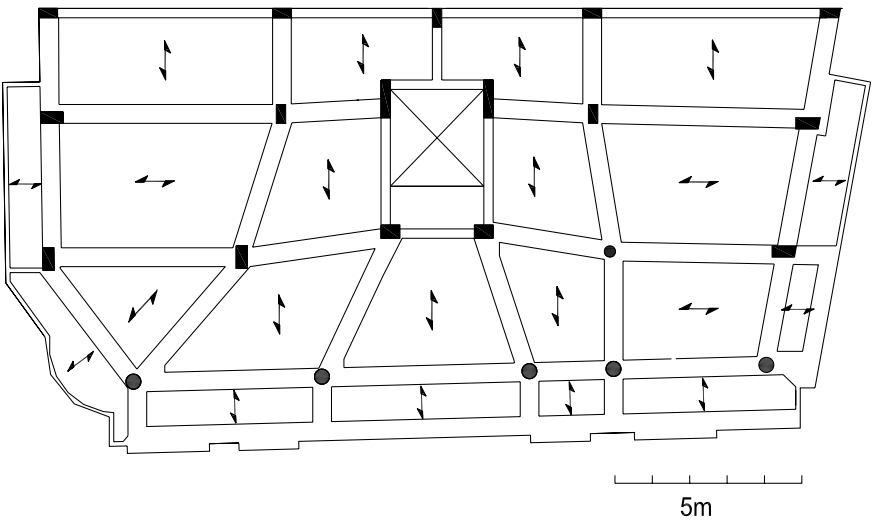

(a)

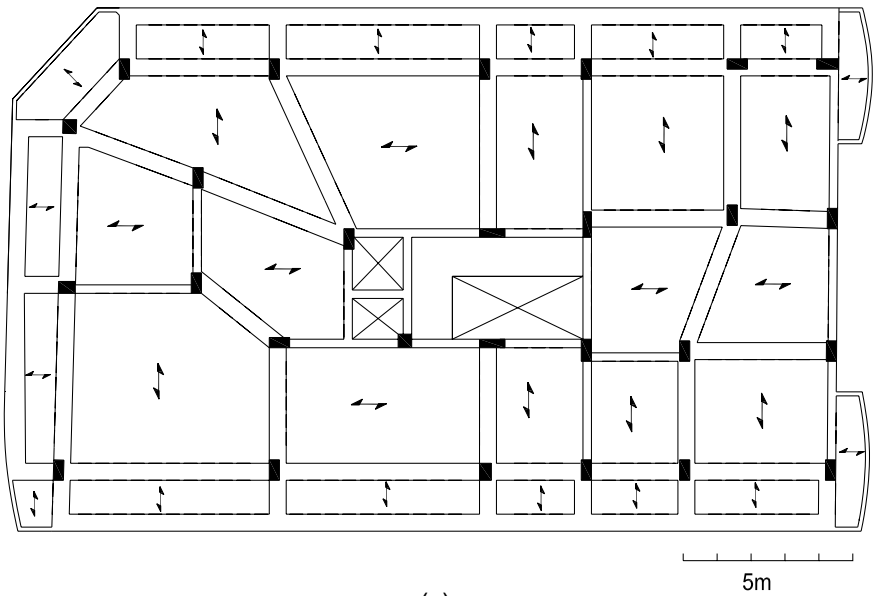

(c)

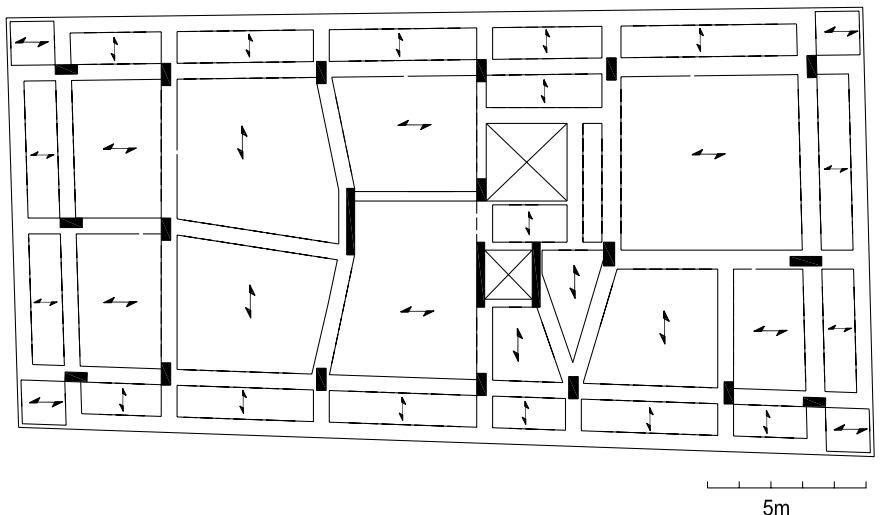

(b)

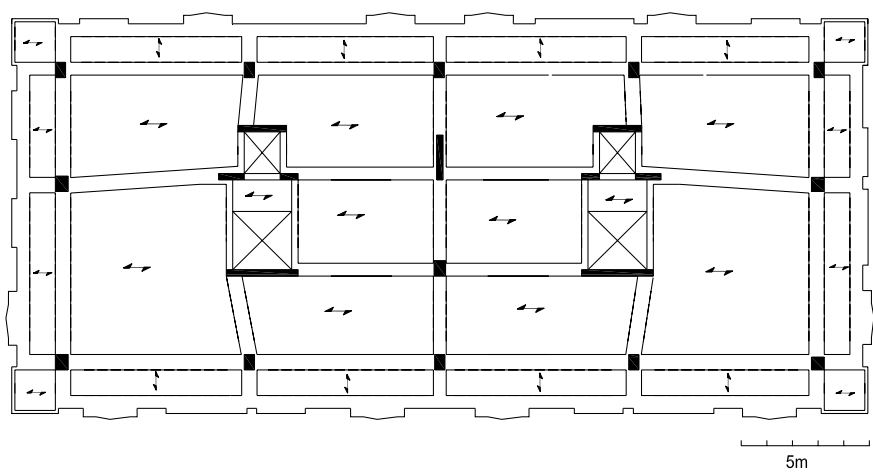

(d)

Fig. 4. Representative floor framings of asmolen structures: (a) structural plan of building 2 in Table 1; (b) structural plan of building 3 in Table 1; (c) structural plan of building 4 in Table 1; (d) structural plan of building 6 in Table 1

between the joists are supported by a 70- to 90 - $\mathrm{mm}$ thick slab. Joists and girders have spans that vary between 2 to $7 \mathrm{~m}$. Having the joists in only one direction produces long spans. The minimum beam depth for a high-ductility RC frame in Turkish seismic code is $300 \mathrm{~mm}$. Satisfying this requirement and at the same time attempting to have the most shallow beams results in beam depths in the range of $300-350 \mathrm{~mm}$. Serviceability requirements dictate maximum spans of 6-7 $\mathrm{m}$ with aforementioned depths. The combination of long spans with shallow beams results in very flexible structures. Beam width is required by the code to be less than or equal to column width plus two beam depths. Use of the beam depth in defining beam width is in line with the pre-2011 revision of ACI 318 requirements. In practice, eccentric beamcolumn connections are used without any limitation and are in fact very common.

Designers typically attempt to change the orientation of the joists with the belief that it would be a solution for the flexibility problem. Typical multiunit and residential characteristics of these structures necessitate a central stairway that serves units at every floor. As a result, structural grids are highly irregular, with discontinous frame lines and skewed beam axes. Examples of such framing are presented in Fig. 4. Plans in (a) and (c) are typical examples of such applications.

Limited beam depth and architecturally decided span lengths in asmolen structures result in increased column sizes to satisfy the displacement requirements. Oversized and oblong columns are the outcome. Larger column size and limited beam flexural stiffness create a favorable condition in terms of the strong-column, weak-beam concept. Due to code requirements and cross-sectional geometry, columns typically have eight or more longitudinal reinforcing bars with well-distributed transverse reinforcement. Longitudinal reinforcement varies between $\Phi 14$ to $\Phi 18$ diameter deformed bars, and transverse reinforcement is typically $\Phi 8$ deformed bars. Minimum anchorage length of 20-bar diameters defined by ACI-ASCE-352-02 requires a beam depth of 280 to $360 \mathrm{~mm}$ for $\Phi 14$ to $\Phi 18$ bars. There is no control on beam and column main-bar anchorage lengths.

The code TEC-2007 does not impose any requirements on confinement of longitudinal beam bars anchoring outside the column core. Furthermore, there is no reference to torsional capacity of the spandrel beams.

\section{Asmolen Buildings in Turkish Practice}

Seven existing asmolen buildings are studied as examples of current Turkish practice from their design drawings. Structures are designed according to TEC-2007. The number of stories ranges from three to six. A nominal concrete strength of $30 \mathrm{MPa}$ is designated, except for one building, which has $25 \mathrm{MPa}$. Steel reinforcement has a yield strength of $420 \mathrm{MPa}$. Floor areas vary from 220 to $520 \mathrm{~m}^{2}$ per story. Four of these structures have basements. Foundations are either strip footings or mat floors. Floor spans vary from 2.0 to $7.5 \mathrm{~m}$. The majority of the beams have a rectangular section of 
500 by $320 \mathrm{~mm}$. Other beam sizes are 600 by $320 \mathrm{~mm}$ or 700 by $320 \mathrm{~mm}, 320 \mathrm{~mm}$ being the depth of the shallow beams. It should be noted that a mixed use of regular beams and wide beams is common, which could be taken as an indication of architectural preference rather than cost-minimization issues in the decision on the use of asmolen floors. Regular beams are typically sized as 250 by $500 \mathrm{~mm}$. Except in one of the structures, the first story is taller than the upper stories. The ratio of the first story height to upper levels varies from 1.1 to 1.4. Typical stories have a height of about 3 meters. Columns typically have rectangular cross sections. Typical column sizes are 250 by 500 or $600 \mathrm{~mm}$ and 300 by 600 or $700 \mathrm{~mm}$. Structural walls typically have $250-\mathrm{mm}$ thickness. Two of the buildings are on soil type Z3 (stiff soil, $T_{b}=0.6 \mathrm{~s}$ ), and others are on soil type Z2 (shallow stiff soil, $T_{b}=0.4 \mathrm{~s}$ ) per the TEC2007 classification. Design peak ground acceleration is $0.4 \mathrm{~g}$ for all buildings, i.e., buildings are located in the highest seismicity regions of Turkey.

Planar frame axes of RC structures in Turkey are often disrupted or shifted due to architectural or construction decisions that impair the structural behavior. Asmolen structures have similar deficiencies. As examples of such applications, structural plan layouts of representative frames are presented in Fig. 4. Arrows in spans show the direction of the joists. Floor plans of four out of seven studied buildings are presented in the figure. These structures are designed as residential buildings with multiple units on every floor. A central service area exists for accessing the units. As can be observed from the plans, discontinuous and skewed frame axes typically originate from service areas (openings in the plans are typically stairs and elevator shafts). Structures with plan (a) have only one frame line that is following the general directions of the building plan; all other axes are either skewed or on a broken line, and the structure with plan (c) has only two continuous frames in both directions. Discontinuity or disruption of frame lines not only limits frame action and causes an increase in flexibility but also increases the irregularity in the buildings.

Another common feature is heavy overhangs. All of the example buildings have overhanging floors along most of the perimeter. As a result, total mass supported by the structure increases.

As can be observed from the floor plans presented in Fig. 4, beams frequently have eccentric and skewed connections with columns. There are extreme applications in practice. Such a joint is presented in Fig. 5. Because existing experimental evidence is on

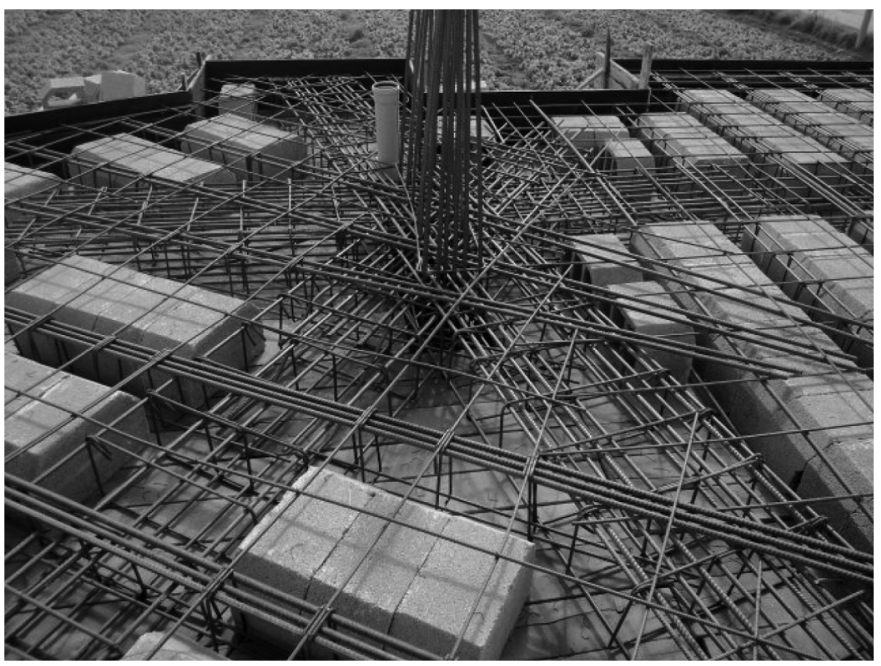

Fig. 5. Example of a skewed beam-column connection in an asmolen floor (image courtesy of Erdoğan Sayın) concentric wide-beam column connections, it is not possible to rate the behavior of such connections. Conversely, extrapolating from existing evidence, it is highly likely that such connections could start losing their stiffness at low levels of deformation and have lower strength than expected.

Studied structures are modeled numerically to obtain uncracked and cracked periods and the modal properties to determine the deformation demands under design-level earthquake loads. The software ETABS (2004) is used as the structural modeling platform. Three-dimensional linear models are implemented. Uncracked periods are obtained by using nominal values of material and sectional properties. Cracked periods are obtained by decreasing the flexural stiffness of members by the predefined values defined in TEC-2007. Reduction coefficients of the code are defined based on member type, in a fashion similar to ATC-40 (Applied Technology Council 1996). Even though calculations indicate that five out of seven buildings have a torsional response in their first modes, all buildings satisfy the code requirements that allow their design to be based on the equivalent static lateral load method. Calculated periods of the buildings are presented in Fig. 6. Also shown in Fig. 6 are the building height versus period data from several RC frame buildings as reported by Yakut (2008). Yakut calculated the periods of a set of existing pre-2007 code design (including mostly 1975 and 1997 code-designed buildings) RC moment-frame structures that are typical to Turkish practice. Yakut indicated that the main trend in periods of these structures follows the period definition in the 1997 Turkish code. Longer asmolen building period values indicate that these structures are more flexible compared to typical pre-2007 code RC moment-frame systems. Regular moment frames per the 2007 code should be expected to be stiffer than 1975 code-designed frames, solely because of an increase in design demands. It should be noted that Yakut included effects of infill walls in his calculation, whereas no such consideration is made in the current study.

The effect of infill walls on the period of RC frames is studied by Koçak and Yıldırım (2011). Geometry and size of the infill, amount of filled bays, amount of existing opening, and number of stories in the building are dominant parameters in defining the effect of infill walls on building period. Koçak and Yıldırım (2011) proposed a model for effect of infill walls on RC frame periods. They considered a weak infill material that is typical to Turkey. Using their model and assuming that $30 \%$ of the bays are effectively filled, a decrease of about 25 to $30 \%$ could be expected in building periods. A $25 \%$ reduction in period could be accepted as a general value for the buildings studied.

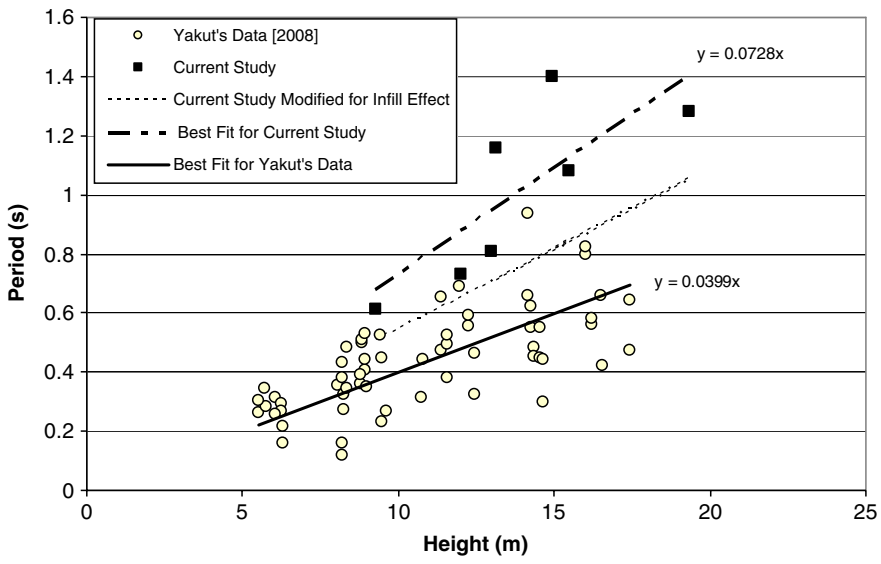

Fig. 6. Comparing natural period versus height relation of studied buildings with the data reported by Yakut (2008) 
If best-fit lines are assumed to define the main trends in change of period by height of the buildings, it could be observed from Fig. 6 that asmolen buildings designed per TEC-2007 requirements are about $40 \%$ softer than regular RC moment frames that are designed per pre-2007 TECs.

\section{Calculated Displacement Demands of Studied Structures}

It is established that the natural periods of structures are important indicators of earthquake displacement demands. Two alternative methods are used to calculate displacement demands of the structures under consideration: the method developed by Lepage (1996) and the TEC-2007 (TCBİB 2007) method.

Based on the extensive data from shaking table tests and numerical studies, Lepage demonstrated that nonlinear spectral displacement demand of RC structures could be estimated from linear acceleration demand, cracked period of structures, and characteristic period of the ground motion. Cracked period of a system is

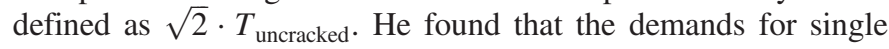
degree of freedom systems can be expressed as

$$
S_{d}= \begin{cases}\frac{F_{a} \cdot \alpha \cdot g}{(2 \pi)^{2}} \cdot T_{\text {cracked }}^{2} & \text { for } T<T_{g} \\ \frac{F_{a} \cdot \alpha \cdot g \cdot T_{g}}{(2 \pi)^{2}} \cdot T_{\text {cracked }} & \text { for } T>T_{g}\end{cases}
$$

where $F_{a}=$ acceleration amplification factor (as representative of a wide range of earthquakes; a value of 3.75 is recommended for oscillators with $2 \%$ damping); $g=$ gravitational acceleration; $\alpha=$ peak ground acceleration expressed as a coefficient of the gravitational acceleration; and $T_{g}=$ characteristic period of ground motion (can be approximated by the period at which nearly constant acceleration region ends).

TEC-2007 states that nonlinear spectral displacement demand could be estimated by a formulation that is based on an "equivalent displacement rule." The cracked period of the structure is used to define the linear displacement demand. The formulation has a correction factor for periods less than the corner period $\left(T_{b}\right)$ of the design spectrum. The variable $T_{b}$ estimates the period where the design spectrum changes from the nearly constant acceleration region to the nearly constant velocity region. Nonlinear spectral displacement for periods larger than $T_{b}$ is considered to be equal to linear spectral displacement demand.

Lepage's method is idealized for buildings with a fundamental mode that does not have any rotational component. The TEC-2007 approach accepts some rotation for modes in the considered loading direction. Noting that the torsional component of modes causes further demands on some members of structural systems, a calculation under pure translational demands will provide lower bounds for displacement demands. Nonlinear spectral displacement demand of considered asmolen buildings in terms of highest interstory drift demands on studied buildings is presented in Table 1.

The displacement demand based on TEC-2007 varies between 1.9 and $3.3 \%$. In contrast, Lepage's method yielded values between 2.1 to $3.6 \%$. Calculated maximum interstory drift ratios are in agreement for soil type Z2. Lepage's method results in higher values for soil type Z3. Major differences between the two methods arise from definitions of selected design ground motions, crackedsection period of structures, and distribution of spectral displacements along the height of the structures. There are other approaches for calculating nonlinear spectral displacements. A common feature in all methods is the high uncertainty. The FEMA 273 (FEMA 1997) and FEMA 440 (FEMA 2005) reports recommend that structures should be checked for at least $150 \%$ of target displacement as calculated by the methods in the respective reports. It is noted that target displacements represent the mean values, and there is considerable scatter about the mean. The TEC-2007 and Lepage methods are not immune to this recommendation. Considering that uncertainties about ground motions are open to further discussion, in order to be on the safe side, calculated values should be taken into consideration but with caution.

Checking of linear displacement demands of the studied structures indicate that all satisfy the TEC-2007 2\% drift limitation under equivalent static forces. It is observed that designers do not prefer to use structural walls as main lateral elements. Structural walls seem to be used only to satisfy the code displacement limit. Buildings 3 [Fig. 4(b)] and 6 [Fig. 4(d)] are examples of such an approach. Considering the number of stories, these buildings have the highest periods.

The high interstory drift ratios presented in Table 1 are an indication of the vulnerability of these structures. The buildings listed in Table 1 were designed to the requirements of TEC-2007. As mentioned in previous sections, skewed or eccentric beam-column joints, improperly reinforced spandrel beams, and insufficient development lengths for beam and column main reinforcements make any attempt to model these structures in the nonlinear range inconclusive. Numerical models could be developed, but it is not likely that the results will be accurate. Nevertheless, in order to examine whether TEC-2007 requirements would lead to safe designs considering displacement capacity only, a generic building is designed. In this building, the aim is to have a design that is free of early strength and stiffness degradation due to connection and detailing problems.

Table 1. Calculated Maximum Interstory Drift Demands of Studied Buildings

\begin{tabular}{|c|c|c|c|c|c|c|c|c|}
\hline \multirow[b]{2}{*}{ Building } & \multirow[b]{2}{*}{$\begin{array}{c}\text { Building } \\
\text { height }(\mathrm{m})\end{array}$} & \multirow[b]{2}{*}{$\begin{array}{l}\text { Number } \\
\text { of stories }\end{array}$} & \multirow[b]{2}{*}{$\begin{array}{l}\text { Soil type, } \\
\left(T_{b}, \mathrm{~s}\right)\end{array}$} & \multirow[b]{2}{*}{$T(\mathrm{~s})$} & \multirow[b]{2}{*}{$\begin{array}{c}T_{\text {cracked }} \text { per } \\
\text { TEC-2007 (s) }\end{array}$} & \multirow[b]{2}{*}{$\begin{array}{l}T_{\text {cracked }} \text { per } \\
\text { Lepage }(\mathrm{s})\end{array}$} & \multicolumn{2}{|c|}{$\begin{array}{c}\text { Maximum interstory } \\
\text { drift }(\%)\end{array}$} \\
\hline & & & & & & & $\begin{array}{l}\text { TEC-2007 } \\
\text { method }\end{array}$ & $\begin{array}{c}\text { Lepage's } \\
\text { method }\end{array}$ \\
\hline 1 & 9.3 & 3 & Z3 (0.6) & 0.6 & 0.9 & 0.9 & 2.4 & 3.4 \\
\hline 2 & 12.0 & 4 & $\mathrm{Z} 2(0.4)$ & 0.7 & 1.1 & 1.0 & 1.9 & 2.2 \\
\hline 3 & 13.1 & 4 & $\mathrm{Z} 2(0.4)$ & 1.2 & 1.7 & 1.6 & 2.8 & 2.1 \\
\hline 4 & 13.0 & 4 & $\mathrm{Z} 2(0.4)$ & 0.8 & 1.3 & 1.1 & 2.1 & 2.1 \\
\hline 5 & 15.5 & 5 & $\mathrm{Z} 2(0.4)$ & 1.1 & 1.5 & 1.5 & 2.2 & 2.4 \\
\hline 6 & 15.0 & 5 & $\mathrm{Z} 2(0.4)$ & 1.4 & 2.1 & 2.0 & 3.3 & 3.3 \\
\hline 7 & 19.3 & 6 & Z3 (0.6) & 1.3 & 1.7 & 1.8 & 2.8 & 3.6 \\
\hline
\end{tabular}




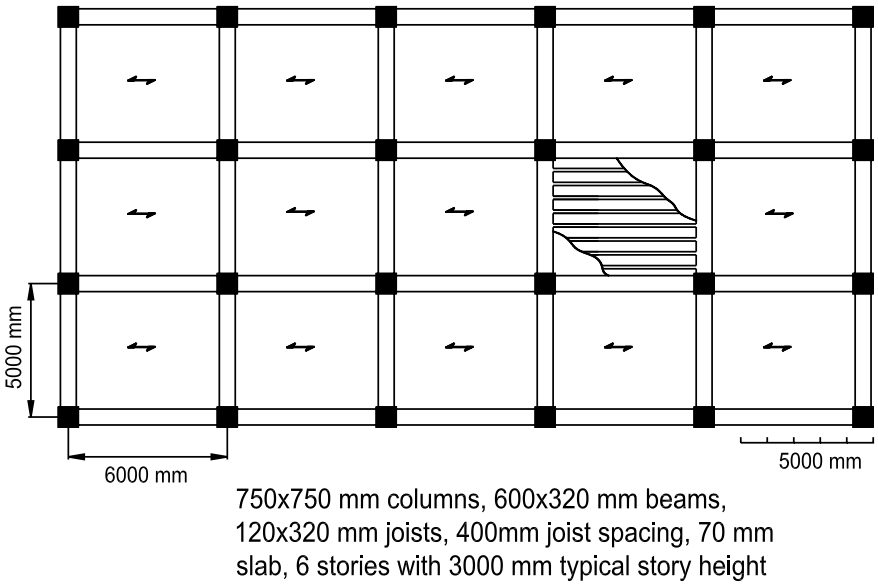

Fig. 7. Plan of building designed to evaluate sufficiency of TEC-2007 requirements for wide-beam buildings

\section{Example TEC-2007 Building Free of Typical Deficiencies}

A six-story building with asmolen floors and 3-m story heights is designed. A taller ground story is not considered to avoid soft-story effects. The building is considered to be located at a soil site with $T_{b}=0.6 \mathrm{~s}$ (Z3 per TEC-2007) and the in highest seismic zone, which has $0.4-\mathrm{g}$ peak ground acceleration. Concrete with a compressive strength of $30 \mathrm{MPa}$ and reinforcing steel with a yield strength of $420 \mathrm{MPa}$ are used. Floor framing member sizes and spans are selected in accordance with the current practice in Turkey. Column dimensions are determined by TEC-2007 displacement requirements, and final sizes are 750 by $750 \mathrm{~mm}$. As shown in Fig. 7, a regular grid with continuous frame lines is considered. Calculated periods and nonlinear displacement demands of the building are presented in Table 2. Based on the selected material properties and nominal cross sections, the fundamental period of the structure is calculated to be $1.1 \mathrm{~s}$ for a translation mode in the plan longitudinal direction. The T-beams are considered in the analysis to introduce the contribution of the effective slab portions. The TEC-2007 design provisions resulted in an equivalent lateral static load of about $8 \%$ of the total weight of the structure. Application of this lateral load resulted in a maximum interstory drift of $1.8 \%$ in the linear analysis. The calculated drift ratio is within the limits of TEC-2007. The members of the frame are detailed considering the internal forces that are developed under a lateral force reduced by a factor of 8 . The members are detailed to satisfy the high ductility requirements of TEC-2007.

Chapter 7 of TEC-2007 is about evaluation and strengthening of existing RC buildings. Earthquake performance of the example designed building is evaluated according to the procedures defined in this chapter, as if it were an existing building. Considering that column widths are larger than wide-beam widths and all of the beam column axes are orthogonal, members could develop plastic hinges up to the material limits defined by TEC-2007. Column depths are sufficient to develop beam main bars in flexure. The crackedsection period of the structure is calculated based on the procedure defined in TEC-2007 and is found to be $1.7 \mathrm{~s}$ in the longitudinal direction. Based on soil type and peak ground acceleration, roof displacement demand of the structure is calculated as $420 \mathrm{~mm}$. Plastic hinges are defined at the end of each column and beam. Plastic hinge properties are based on the maximum material strain limits as defined in TEC-2007 and the geometry of the members. The ultimate strains that are permitted in unconfined and confined concrete are 0.004 and 0.018 , respectively. Similarly, the ultimate strain in reinforcing steel is 0.06. As defined in TEC-2007, a lateral load profile that is in accordance with the first mode of the system is applied in the lateral direction. The analysis is performed using the ETABS (2004) software. Secondary deformations are considered in the analysis. The pushover curve along the longitudinal direction

Table 2. Calculated Maximum Interstory Drift Demands of Designed Building

\begin{tabular}{|c|c|c|c|c|c|c|c|c|}
\hline \multirow[b]{2}{*}{ Building } & \multirow[b]{2}{*}{$\begin{array}{l}\text { Building } \\
\text { height }(\mathrm{m})\end{array}$} & \multirow[b]{2}{*}{$\begin{array}{l}\text { Number } \\
\text { of stories }\end{array}$} & \multirow[b]{2}{*}{$\begin{array}{l}\text { Soil type } \\
\left(T_{b}, \mathrm{~s}\right)\end{array}$} & \multirow[b]{2}{*}{$T(\mathrm{~s})$} & \multirow[b]{2}{*}{$\begin{array}{c}T_{\text {cracked }} \text { per } \\
\text { TEC-2007 (s) }\end{array}$} & \multirow[b]{2}{*}{$\begin{array}{l}T_{\text {cracked }} \text { per } \\
\text { Lepage }(\mathrm{s})\end{array}$} & \multicolumn{2}{|c|}{$\begin{array}{l}\text { Maximum interstory } \\
\text { drift }(\%)\end{array}$} \\
\hline & & & & & & & $\begin{array}{l}\text { TEC-2007 } \\
\text { method }\end{array}$ & $\begin{array}{l}\text { Lepage's } \\
\text { method }\end{array}$ \\
\hline N1 & 18 & 6 & Z3 (0.6) & 1.1 & 1.7 & 1.6 & 3.0 & 3.2 \\
\hline
\end{tabular}

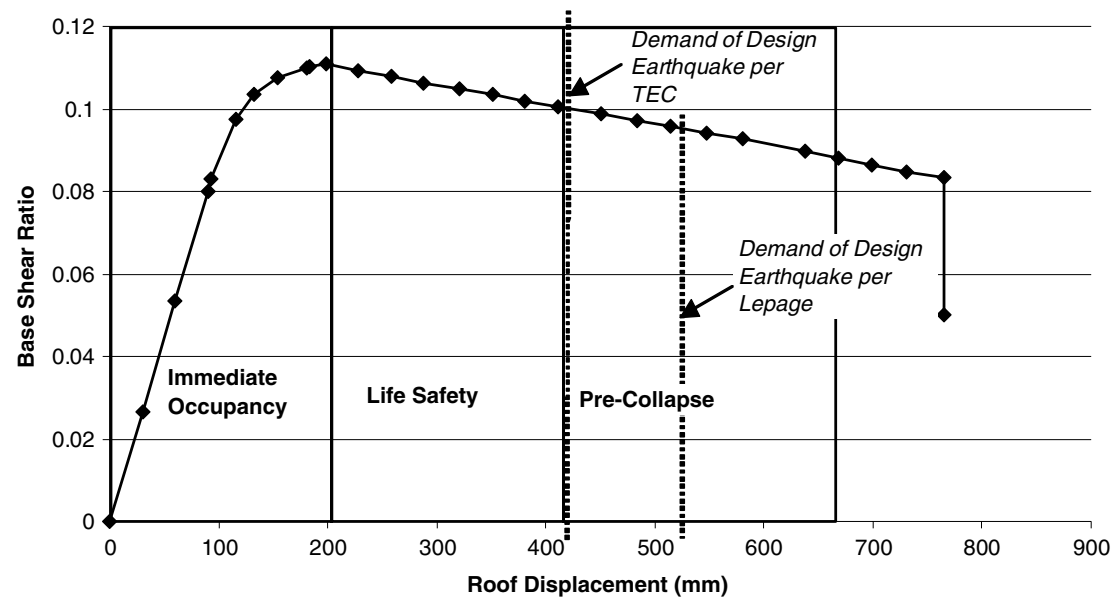

Fig. 8. Performance level of designed asmolen building that does not have typical deficiencies; pushover curve in longitudinal direction 
is presented in Fig. 8. The maximum base shear ratio of 0.11 is reached at a roof displacement of $200 \mathrm{~mm}$. The performance regions according to TEC-2007 are defined in the figure. Based on a calculated displacement demand of $420 \mathrm{~mm}$, the structure is at the early stages of the precollapse performance region. According to the classification of TEC-2007 for residential buildings, life-safety performance should be satisfied. Therefore, according to Chapter 7 of TEC-2007, the designed structure is in an unsatisfactory region. The displacement demand as calculated by the Lepage method is presented in Fig. 8 as well. This value indicates a worse performance.

\section{Discussion of Results}

A review of reports from past earthquakes in Turkey reveals that performance of wide-beam, infill-joist block structures did not receive sufficient attention from earthquake engineers. There seems to be two reasons for this neglect. First, the number of asmolen buildings is relatively small compared to regular RC moment-frame buildings. It can be guesstimated that $10-15 \%$ of total RC frames are asmolen structures in Turkish RC building stock. Second, any possible weakness in asmolen system response is veiled behind the insufficient material strength and detailing applications. In order to get an accurate estimate of the possible effect of asmolen buildings in mitigation and earthquake risk studies, their ratio within the general population of buildings should be investigated. Also, there is a need to study the postearthquake damage ratios of asmolen buildings within the general population of RC frame buildings to differentiate their performance from general $\mathrm{RC}$ building stock due to their systematic behavior.

Studies (Benavent-Climent 2006; Benavent-Climent et al. 2010; Gentry and Wight 1994; Lafave and Wight 2001) show that insufficient anchorage of bars outside the column core and torsion weakness of spandrel beams cause early strength and stiffness losses in wide-beam column connections. Due to unrestrained connection geometry, a skewed frame axis, and lighter detailing requirements, typical wide-beam moment frames constructed in Turkey tend to be weaker and softer than they are intended to be. Existing studies on wide-beam column connections do not provide sufficient information to define the behavior of existing asmolen buildings in Turkey because of a lack of experimental studies. On another front, current modeling techniques are unsatisfactory for realistic analysis of the majority of wide-beam systems in Turkey. Therefore, it is not possible to perform a realistic nonlinear analysis. The means and methods to model such structures should be developed.

Current Turkish earthquake code (TEC-2007) permits design and construction of asmolen buildings as regular high-ductility moment-frame structures. There are no other specific requirements. Investigation of seven existing structures reveals that the equivalent static load approach is governing the design procedure. The main parameter that is controlling the design through code requirements is the $2 \%$ interstory drift limit under design level loads in a linear analysis. Calculation of nonlinear displacement demands of structures indicate that structures need to sustain high displacement values to survive the design ground motions. Because it is not possible to perform a detailed performance-based analysis due to reasons listed in the previous paragraph, a new regular wide-beam building is designed per code requirements in this study. This structure is free of the design deficiencies that are typically observed. Common features of asmolen structures in Turkey, such as a tall ground story and heavy overhangs, are not implemented either. In essence, the designed model asmolen building is better than typical existing asmolen buildings in Turkey. This structure is specifically designed to observe whether TEC-2007 dimensioning requirements result in a design with sufficient capacity to satisfy the displacement demands of the design earthquake. A performance-based analysis procedure per TEC-2007 shows that even avoiding all connection geometry, detailing-related problems, and other irregularities observed in typical asmolen buildings, the building performance is worse than the life-safety level and is at the precollapse borderline. Considering uncertainty in modeling and actual design demands, this is not an acceptable performance.

Existing asmolen buildings in Turkey possess high risk. Earthquake reports indicate that different modes of failure could be expected. There are examples of pre-1997 TEC structures that had brittle column failures contrary to the expectation for strongcolumn, weak-beam behavior in asmolen buildings. Post-2007 TEC structures could possibly have strong-column, weak-beam behavior, but because total loss is expected under design level earthquakes, such a performance is of no real help. It is likely that connection geometry and detailing-related problems could cause premature failures before development of plastic hinges in beams.

Heavy overhangs, soft stories, and discontinuous, shifted, and skewed frame lines weaken the structural system and cause an increase in periods of the structures. Force-based approaches are not very sensitive to changes in displacement capacity and demands under such circumstances. In addition, existing structural modeling platforms are not capable of modeling shifted frame lines that are connected through a column. Under such conditions, either a beamcolumn connection is modeled as a rigid joint or a shift in the beam is not accounted for at all. Strong engineering judgment is needed to perform a design with such features, but there is no experimental study or data to develop such engineering judgment.

Linear trend lines are presented in Fig. 6 as a relationship between building period and building height. Lepage's method (Lepage 1996) proposes that nonlinear displacement demand is a linear function of building period. Therefore, the ratio of trend lines in Fig. 6 could be taken as a measure of relative displacement demands. If the period values in Fig. 6 are used with brevity as a measure to generalize groups of RC regular and asmolen frames, post-1997 TEC asmolen buildings need to have $40 \%$ more displacement capacity than pre-1997 regular RC frames. It should be noted that post-1997 TEC regular RC frames should be stiffer than older regular RC frames. There is no major difference between TEC 1997 and 2007 requirements for regular RC frames. Post-2007 TEC requirements expect asmolen buildings to sustain on average $40 \%$ more displacement demand while satisfying the same ductility requirements.

If the trend lines in Fig. 6 are accepted to be valid with an average story height of $3 \mathrm{~m}$, asmolen buildings are expected to have a fundamental period of about $N / 4$, where $N$ is the number of stories. This number is greater than the general rule of thumb of $N / 10$ for regular RC frames.

\section{Summary and Conclusions}

Even though many wide-beam, infill-joist block frame ("asmolen") buildings collapsed in Turkish earthquakes, research on this type of structural system is very limited.

Seismic code requirements for asmolen buildings have an irresolute path. After the 1967 Adapazarı earthquake their construction was banned. The 1975 code permit seismic design of asmolen buildings if they include structural walls in the lateral load system. Currently, TEC-2007 permits asmolen building designs within a general framework of regular ductile RC moment frames. There are no specific requirements other than limits about beam width. 
A review of existing literature on wide-beam frames indicates that existing Turkish asmolen buildings are vulnerable to early strength and stiffness losses due to improper beam-column connection geometry and detailing. Further weakness is introduced with the heavy use of skewed and disrupted frame lines. There is not sufficient research on the behavior of eccentric wide-beam connections that are permitted by TEC-2007.

Based on an analysis of seven TEC-2007 designed asmolen structures, it can be said that the fundamental period of asmolen structures is about $40 \%$ longer than regular RC moment frames in Turkey. This translates to about a $40 \%$ increase in displacement demand in the nonlinear range.

The argument that asmolen structures could resist higher displacements as a result of inherent flexibility is investigated through a six-story asmolen frame. In order to constrain the investigation to system flexibility behavior, the structure is designed free from deficiencies of beam-column connection geometry and detailing, skewed, and disrupted frame lines. The design is performed according to TEC-2007 requirements. The resulting structure is evaluated per the TEC-2007 evaluation of existing structures section for displacement capacity. The performed analysis shows that the designed structure does not satisfy the performance level demanded by the requirements of TEC-2007.

It is concluded that the inherent flexibility of asmolen buildings and the resulting high displacement demands are the root cause of insufficient seismic performance. Existing force-based design approaches are not satisfactory for identifying and solving the problem. A design approach that takes displacement as the main parameter would be more appropriate. An indirect way could be to limit the period of the asmolen buildings to control the displacement demands. Uncertainty in existing performance analysis procedures and displacement demand calculations should be embraced, and a design should be based on conservative estimates of displacement capacity and demands.

From the results of existing research on wide beams and the performed study, a few implications for TEC-2007 may be proposed. The TEC-2007 requirements for wide-beam column connections should be extended to avoid early stiffness and strength losses due to connection geometry and detailing. Eccentric connections should be avoided until sufficient research is done to understand their behavior. A design method that takes displacement demand into consideration should be embraced.

\section{References}

AFET. (1993). “13 Mart 1992 Erzincan depremi raporu.” Afet İşleri Genel Müdürlüğü, Ankara, Turkey.

American Concrete Institute (ACI). (2011). "Building code requirements for structural concrete." ACI 318-11, Farmington Hills, MI.

Applied Technology Council. (1996). "Seismic evaluation and retrofit of concrete buildings." ATC-40, Redwood City, CA.

Arıoğlu, E., Anadol, K., and Arığlu, Ü. (2007). "Uluslararası deprem mühendisliği açısından önemli bir olgu ve kayıp: 'Güçlendirilmiş adapazarı vilayet binası'." Tarihi Eserlerin Güçlendirilmesi ve Gelece ğe Güvenle Devredilmesi Sempozyumu-1, TMMOB (Union of Chambers of Turkish Engineers and Architects), Ankara, Turkey.

ASCE Committee 352. (2002). "Recommendations for design of beamcolumn connections in monolithic reinforced concrete structures." ACIASCE-352-02, American Concrete Institute, Farmington Hills, MI.

Aschheim, M., et al. (2000). "Performance of buildings." Earthquake Spectra, 16(S1), 237-279.

Baran, E., Mertol, H., and Gunes, B. (2013). "Damage in reinforced concrete buildings during October 23 and November 9, 2011, Van, Turkey earthquakes." J. Perform. Constr. Facil., in press10.1061/(ASCE)CF .1943-5509.0000396.
Bayraktar, A., Altunişik, A., and Muvafik, M. (2013). "Field investigation on the performance of masonry buildings during the October 23 and November 9, 2011, Van earthquakes in Turkey." J. Perform. Constr. Facil., in press10.1061/(ASCE)CF.1943-5509.0000383.

Benavent-Climent, A. (2006). "Influence of hysteretic dampers on the seismic response of reinforced concrete wide beam-column connections." Eng. Struct., 28(4), 580-592.

Benavent-Climent, A., Cahis, X., and Vico, J. M. (2010). "Interior wide beam-column connections in existing RC frames subjected to lateral earthquake loading." Bull. Earthquake Eng., 8(2), 401-420.

Ersoy, U. (1991). Reinforced concrete, Middle East Technical Univ., Ankara, Turkey.

ETABS [Computer software]. (2004). Version 8.4.8, Computers and structures, Berkeley, CA.

FEMA. (1997). "NEHRP guidelines for the seismic rehabilitation of buildings." FEMA 273, Washington, DC.

FEMA. (2005). "Improvement of nonlinear static seismic analysis procedures." FEMA 440, Dept. of Homeland Security, Washington, DC.

Gentry, T. R., and Wight, J. K. (1994). "Wide beam-column connections under earthquake-type loading.” Earthquake Spectra, 10(4), 675-703.

Gulkan, P. (1998). "Turkiye depremleri June 271998 Ceyhan Misis earthquake reconnaissance report, METU-DMC.” METU-EERC, Ankara, Turkey.

Gülkan, P., Gürpınar, A., Çelebi, M., Arpat, E., and Gençoğlu, S. (1978). "Engineering report on the Muradiye-Çaldıran, Turkey, Earthquake of 24 November 1976." National Academy of Sciences, Washington, DC.

Irfanoglu, A., Dönmez, C., Rafael, A., and Rafael, H. (2012). "The Mw 7.1 Erciş-Van, Turkey earthquake of October 23, 2011." EERI April Newsletter, Earthquake Engineering Research Institute, Oakland, CA.

Koçak, A., and Yildırım, M. K. (2011). "Effects of infill wall ratio on the period of reinforced concrete framed buildings." Adv. Struct. Eng., 14(5), 731-744.

Lafave, J. M., and Wight, J. K. (2001). "Reinforced concrete wider-beam construction vs. conventional construction: Resistance to lateral earthquake loads." Earthquake Spectra, 17(3), 479-505.

Lepage, A. (1996). "Seismic drift estimates for RC structures." 11th World Conf. on Earthquake Engineering, Canadian Association for Earthquake Engineering, Ottowa, Canada.

Malley, J. O., Celebi, M., Bruneau, M., Saaticioglu, M., Erdik, M., and Gulkan, P. (1993). "1992 Erzincan earthquake: Buildings.” Earthquake Spectra, 9(S1), 49-85.

Middle East Technical University (METU). (2012). "9 Kasım 2011 Mw 5.6 Van-Edremit depremi sismik ve yapisal hasara ilişkin gözlemler." METU/EERC/IMO 2012-01, TMMOB (Union of Chambers of Turkish Engineers and Architects), Ankara, Turkey.

Okuyucu, D., Kale, Ö., Erdil, B., Caner, A., Askan, A., Akansel, V. H. (2014). "Evaluation of Turkish seismic bridge design practice resulting in a successful seismic performance of highway bridges during the 23 October 2011 Van earthquake, $\mathrm{Mw}=7.1$." J. Perform. Constr. Facil., 10.1061/(ASCE)CF.1943-5509.0000377, 4-12.

Pekin, O. (1967). "Depreme dayanikli bina nasil yapilabilir?." Cumhuriyet, İstanbul, Turkey, 2.

Saatcioglu, M., et al. (2001). "The August 17, 1999, Kocaeli (Turkey) earthquake damage to structures." Can. J. Civ. Eng., 28(4), 715-737.

TC Bayındırlık ve İskan Bakanlığı (TCBİB). (1975). "Afet bölgelerinde yapılacak yapılar hakkında yönetmelik." Ankara, Turkey.

TC Bayındırlık ve İskan Bakanlığı (TCBİB). (2007). "Deprem bölgelerinde yapılacak yapılar hakkında yönetmelik." Ankara, Turkey.

TC Bayındırlık ve İskan Bakanlığı Yapı Malzemesi ve Deprem Araştırma Genel Müdürlügüü (TCBİB). (1983). "30 ekim 1983 erzurum-kars depremi raporu.” TC Bayındırlık ve İskan Bakanlı̆̆ı, Ankara, Turkey.

TC İmar ve İskan Bakanlığı Deprem Araştırma Enstitüsü Başkanlığı (TCIİB). (1975). "Lice depremi raporu." TC İmar ve İskan Bakanlığı, Ankara, Turkey.

Yakut, A. (2008). "Capacity-related properties of RC frame buildings in Turkey.” J. Earthquake Eng., 12(sup2), 265-272.

Yarar, R., Demir, H., Kumbasar, N., and Trupia, A. (1970). "Gediz depremi incelemelerine ait ön rapor.” İTÜ Deprem Mühendisliği Yayınları No: 1, İstanbul, Turkey. 